\title{
Costume Form and Appearance in the Concept of Performance Keroncong Music in Bandung:
}

\author{
Symbols of Past and Now Collaboration
}

\author{
Hery Supiarza* \\ Film and Television Study Program, Department of Art and Design Education \\ Universitas Pendidikan Indonesia \\ Bandung, Indonesia \\ *herysupiarza@upi.edu
}

\begin{abstract}
This research illustrates the concept of costume collaboration and the formation of young keroncong music performances in Bandung, which is collaborating the past with the present situation. With this concept, keroncong music as music that is less popular among young people in Bandung experienced significant changes in terms of giving a new discourse. O.K. De Oemar Bakrie is used as the main source in this research. Through qualitative methods and triangulation techniques information is collected as valid data. This research found that the Indonesian struggle style costumes during the Soekarno era, especially the cap (songkok), gave an image of the past romanticism to the audience of today's keroncong music. Today's formations imaged with the appearance of large ensembles are a form of collaborative performance that appeals to young people today. It can be concluded that this concept can attract the interest of young people in the city of Bandung to enjoy keroncong music and preserve it.
\end{abstract}

Keywords-keroncong music, costume, performance, symbol, collaboration

\section{INTRODUCTION}

A music stage with a large audience is the dream of every music group. To achieve the success of music performances on the popular music stage, of course, must be equipped with important elements to support these musical performances. Elements of musical performances are not only aspects of composition, arrangement or tidiness in playing, but stage settings, lighting and most importantly the costumes of the musicians. In music performances the visual aspect has a role that sometimes overcomes the audio aspect as the music culture itself, visualization is an impression and important value for the audience [1]. Concert clothing and physical attractiveness are two components of the visual code that are relatively unexplored in the search for musical performances [1], even though social code and symbolic impressions are constructed by clothing and physicality in a show. Even the quality of performances will be judged by the audience based on visualization rather than musical quality [2].
Keroncong music as a product of hybrid culture has a visualization style that has been constructed since a long time ago, dressed modestly, elegantly and characterizes refinement. Hybrid culture can also be called transculture, a culture that is built by the principle of crossing, that is, culture has been contaminated (mutually) by various other plural entities outside of itself [3]. Likewise, costume as a visualization in the context of this study is a trajectory of past and present elements. The crossing that is meant in this research is the collaboration of past costumes, namely the Indonesian style of dress in the era of independence and Indonesia today. The era of independence was represented by Sukarno with a black cap. Peci entered the area of symbolic thinking of Indonesian leaders in the history of the nation's journey. How a peci becomes a "visual move" to symbolize that its use is a nationalist and religious leader, especially Soekarno as the originator of the birth of Pancasila and who popularized the cap as a symbol of nationalism, making the cap a very interesting thing [4]. Cap one of the symbols used by O.K. De Oemar Bakrie, to pursue romantic visualization of the past, and whether the symbols of this visualization successfully represent his intentions, this is a big question in this research.

\section{METHODS}

Qualitative methods with triangulation techniques were used in this study. Triangulation techniques aim to use multiple investigations, multiple sources or data, or multiple methods to confirm emerging findings. Triangulation is essentially a multimethodal approach that researchers take when collecting and analyzing data. The basic idea is that the phenomenon under study can be well understood so that high-level truths can be obtained if approached from various points of view [5]. In this study, triangulation techniques are used to reduce bias so that accurate data can be obtained through observation, interviews, and literature studies. 


\section{RESUlTS AND DiscUSSION}

One of the characteristics that become the identity of a music group is costume / clothing, costumes have symbols for individuals and groups. Costumes function as an effective communication tool in social interactions, costumes affect the formation of identity for oneself and others. The individual self combines identities based on the positions assigned and achieved in social structures, especially those that govern kinship, economic, religious, and political relationships. The identity that costumes / clothing communicates is also influenced by technology and society's moral and aesthetic standards for costumes. The type and special nature of costumes that communicate identity can change over time in response to changes in the economy, demographics, and other societies [6]. O.K. De Oemar Bakrie understands how the role of costumes is something that is important to their identity as a group, so they are looking for a costume model to represent their thoughts, a goal that is contained in the keroncong music that is carried.

As a keroncong group inspired by the form of keroncong music in Bandung in the 1920-1930s, and as young people today, they finally agreed to choose two styles of dress, (1) the costume / clothing model of the era of the struggle for the nationalist movement, such as Soekarno, Moh. Hatta. M. Yamin and so on, wearing a black cap, white shirt and shiny loafers, (2) a surfer costume / outfit that is identical to a floral shirt, sea view, bright colors and knee-length jeans and sports shoes.

According to the researcher, the way of dressing in costumes with these two models aims to create a communication system that is more familiar to the audience. The intention is to communicate about the keroncong music they reconstructed from the past. Spoken by Gian Nurpasa (interview, March 5, 2019) 'The style of the cap, black sonkok and white shirt, we are inspired by the condition of old school keroncong (keroncong Bandung in the 20s), where most of the way of dressing is dominated by black and white clothes. , and through the reconstruction of this dress, we can feel the keroncong spirit of the independence and pre-independence era, this model costume applies to the proclaimers and other fighters, so with that we hope that the spirit of freedom absorbs in us, who also play keroncong by freeing brasswind instruments and woodwind, as well as traditional Sundanese lute and flute musical instruments can be immersed in our keroncong music'.

Several times the researchers saw their appearance by dressing like this, the researchers saw that they were very comfortable with the clothes they were wearing, even though their position in playing keroncong was always standing, not sitting, in terms of the position of playing keroncong O.K. De Oemar Bakrie is always standing, (usually conventional keroncong music players sit on chairs and only bass players stand). The comfort of how to dress is based on the confirmation of the researcher and the player and the confirmation of the researcher with the audience. The audience said that they seemed to see the appearance of musicians from the past, the early days of Indonesian independence - as they often saw when they saw photos of books on the history of Indonesian independence. This way of dressing leads the audience into the romanticism of the past that O.K. reconstructed. De Oemar Bakrie is in order to communicate the atmosphere of the past to the audience.

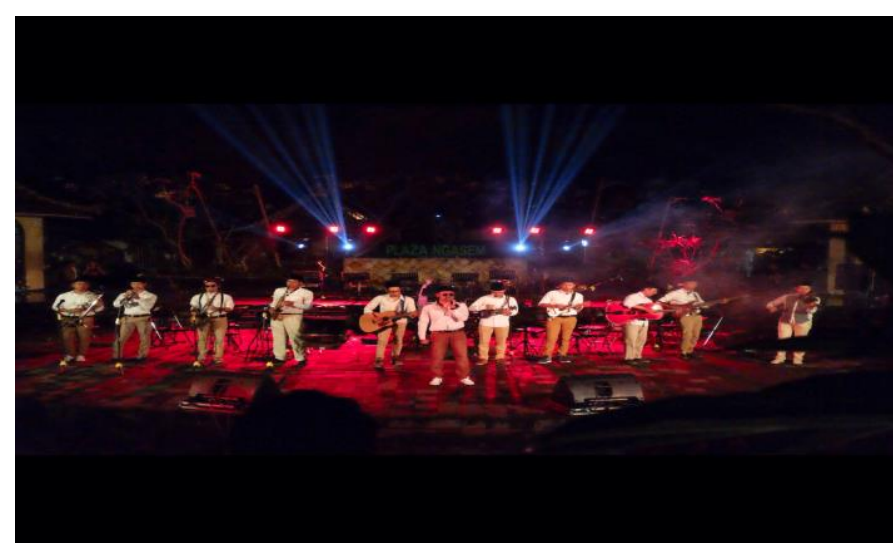

(Documentation: O.K. Oemar Bakries, repro scane 2016)

Fig. 1. How to dress O.K. De Oemar Bakrie keroncong symphony in Yogyakarta November 2017.

Figure 1 shows the O.K. De Oemar Bakrie was dressed in a black and white style, standing up to play keroncong music. The position while standing is something that is not common in the position of playing keroncong music, based on the researcher's interview with them, they want to show that the position of playing keroncong music which tends to be stiff (when sitting) must be innovated and adapted to the conditions of the times, and let young people treat the music. keroncong felt comfortable for the young people themselves.

Regarding the formation / position of playing keroncong music by O.K. According to the researcher, De Oemar Bakri, in addition to the interests of performing arts to make it more attractive, technological advances have made it possible to play keroncong music in a standing position, because with today's technology, musical instruments that are usually constrained by loudspeaker problems can be solved by using pickups, namely a digital instrument that is planted in a musical instrument that functions as a mic, even wirelessly (without cables). So that with this tool, players can freely go to and fro without a hitch. Meanwhile, in the past, before this technology was invented, musical instrument players had to stay where the microphone was positioned. In the future, the position of playing a musical instrument while sitting became "standard" (the aesthetic part of treating keroncong instruments) and this was agreed upon by the parents' group by acclamation and was declared part of politeness. According to the researcher, the position of playing the keroncong instrument by standing is a representation of the ideas of young people as agents of change, the construction of the past is reconstructed in the embodiment of contemporary ideas.

How to dress / costume O.K. De Oemar Bakrie, is a language of communication delivered to be read as a historical 
treatise by the audience. With their communication style, young people in the millennial era try to present a reconstruction of keroncong music as an arena of change for the urban culture of Bandung's youth. O.K. De Oemar Bakrie, also presented a modern way of dressing based on musical trends, such as the way the reaggae or ska children dressed in love (see figure 2). How to dress up in bright colors, sea, landscape or tree shirts with skateboarding youth style shorts, 80 s trend BL glasses and sports shoes. This way of dressing is their strategy to get involved in the Bandung City indie label music movement. In addition, it is intended by them to be open to emerging trends, and keroncong music as a hybrid culture is displayed in its habitat.

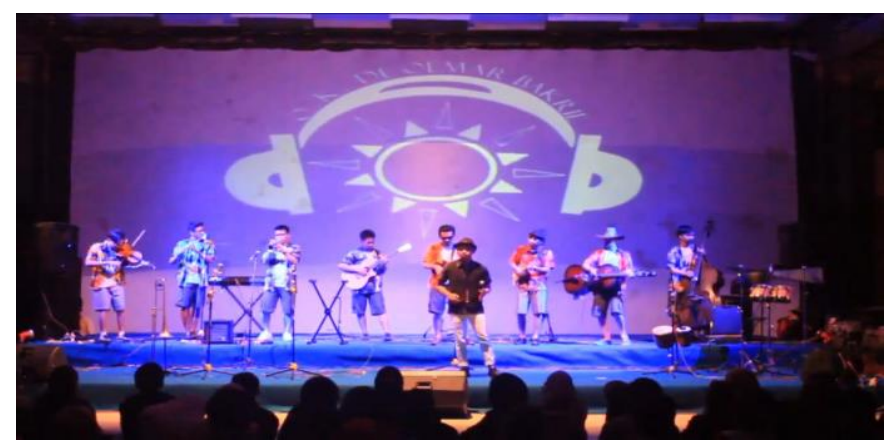

(Documentation: O.K. De Oemar Bakrie, repro scane 2016)

Fig. 2. Dressed as Ska Band Players, longlife keroncong 2014 event at UPI Campus.

This way of dressing shows that O.K. De Oemar Bakrie is a young person who is updating to the times, young people who can interact socially according to their conditions and environment, they are not fanatical about any kind of music. They tried to offer, that how to dress is one thing that must be considered by a group. Apart from being a group identity, costumes are a communication medium for their social environment. For O.K. De Oemar Bakrie, costume is seen as a cultural phenomenon, so costume is a practice of meaning that takes place in everyday life, which helps shape culture as a system of general meaning.

Therefore, costume is a place for humans to communicate, experience, explore and produce social order [7]. In Roland Barthes' Fashion System theory, there are three categories that build the fashion system theory, namely Image Clothing, Written Clothing, and Real Clothing. In the Fashion System, the meaning of fashion symbolization can be seen through photos, writings, and costumes that are being worn. These symbols are interpreted in every moment, where O.K. De Oemar Bakrie in costume. At the level of image clothing, the O.K. costume De Oemar Bakrie can be interpreted as a cultural economy, where an economic and practical process occurs as a cultural phenomenon.
The lineups in the O.K. De Oemar Bakrie is performed in a standing position, but the position where the keroncong player is maintained, namely the order of the chak and the choke side by side, then the cello is close to the bass and the guitar is placed on the side, usually the guitar and bass are on the left or right edge of the cuk, cak and cello, then the left and right edges are melodic musical instruments, namely flute and violin. For auxiliary blow formation, O.K. De Oemar Bakrie adopted the big band swing, which was collected in a single unit consisting of trumpet, trombone and saxophone, so that when viewed from the audience the shape was horizontal. This position arrangement greatly affects the appearance during the show, as well as providing space for performance activities, as well as for the needs of the tone color or sound color produced.

\section{CONCLUSION}

This study sees that the need for costumes in keroncong music performances today is very important. This is one way of communicating in a visual context to become a character and symbol of a keroncong group. Costumes become objects where the audience can identify the existence of a group in the arena stage of the show. O.K. De Oemar Bakrie has succeeded in becoming a representation of the collaboration between the heyday of keroncong music in the past and the present. Through costume, O.K. De Oemar Bakrie shows the romanticism of the history of keroncong and the present reality and has successfully communicated keroncong as a kind of music to be proud of. Through his appearance, O.K. De Oemar Bakrie succeeded in presenting keroncong music with a new visualization so that young people were interested in playing keroncong music. What did O.K. De Oemar Bakrie can be a reference for keroncong music activists to consider the form of keroncong music performances in terms of costumes today.

\section{REFERENCES}

[1] S. Kawase, "Importance of Communication Cues in Music Performance according to Performers and Audience," International Journal of Psychological Studies, vol. 6, no. 2, pp. 49-64, 2014

[2] E. Samspon, New Costume Practices and Performances New Costume Practices and Performances. Internationa Conference and Exhibition of Costume, (March). Helsinky, finlandia: Departemen of Film, TV and Scenography Aalto University, Shool of Art, Design and Architecture, 2015

[3] Y.A. Piliang, "Retakan-retakan Kebudayaan: Antara Keterbatasan dan Ketakberhinggaan,” Melintas, vol. 25, no. 1, pp. 75-92, 2009.

[4] R. Kertamukti, "Komunikasi Simbol: Peci Dan Pancasila," Jurnal Komunikasi Profetik, vol. 6, no. 1, pp. 53-66, 2013.

[5] M. Zamili, "Menghindar Dari Bias: Praktik Triangulasi dan Kesahihan," Jurnal Lisan Al-Hal, vol. 7, no. 2, pp. 283-304, 2015.

[6] M.E. Roach-Higgins and J.B. Eicher, "Dress and Identity," Clothing and Textiles Research Journal, vol. 10, no. 4, pp. 1-8. 1992.

[7] R. Barthes, Fashion system. New York: Hill and Wang, 1983. 